\title{
Glacier recession and human vulnerability in the Yanamarey watershed of the Cordillera Blanca, Peru
}

\author{
Jeffrey T. Bury • Bryan G. Mark • Jeffrey M. McKenzie • Adam French • \\ Michel Baraer • Kyung In Huh • Marco Alfonso Zapata Luyo • \\ Ricardo Jesús Gómez López
}

Received: 7 April 2009 / Accepted: 18 March 2010 / Published online: 15 June 2010

(C) The Author(s) 2010. This article is published with open access at Springerlink.com

\begin{abstract}
Glaciers in the Cordillera Blanca, Peru, are undergoing rapid retreat, in large part due to climate change. These changes are significantly altering water availability in the region and pose critical risks to local populations that are highly dependent on these resources for livelihoods. We examine these issues through an interdisciplinary and linked evaluation of hydrological change and livelihood vulnerability in the Yanamarey watershed. Physical observations of the Yanamarey glacier show acceleration in frontal retreat at a rate of $8 \mathrm{~m} \mathrm{decade}^{-1}$ since 1970 , accompanied by total volume loss on the order of $0.022 \mathrm{~km}^{3}$. Hydrological and hydrochemical analyses document a possible transformation of stream flow over the past decade as the seasonal storage capacity of the glacier has degraded. Recent stream discharge measurements from the proglacial lake below the glacier are more coincident with the highly variable seasonal precipitation than they were during the 1998-1999 hydrological year. Local household perceptions of glacier recession and seasonal hydrological variability agree with this trend, which is increasing human vulnerability in the watershed. Household case-study survey results demonstrate that
\end{abstract}

J. T. Bury $(\varangle) \cdot$ A. French

Department of Environmental Studies, University of California, Santa Cruz,

1156 High Street, Santa Cruz, CA 95064, USA

e-mail: jbury@ucsc.edu

B. G. Mark · K. I. Huh

Department of Geography, The Ohio State University,

1036 Derby Hall, 154 North Oval Mall, Columbus, OH 43210-1361, USA

J. M. McKenzie · M. Baraer

Earth and Planetary Science, McGill University,

3450 University Street, Montreal, PQ H3A 2A7, Canada

M. A. Zapata Luyo · R. J. Gómez López

Autoridad Nacional del Agua, Unidad de Glaciología y Recursos Hídricos,

Avenida Confraternidad Internacional Oeste 167, Huaraz, Peru 
shifting water resources, increasing weather extremes and climate-related threats to tourism are all new vectors of vulnerability for household livelihoods.

Keywords Climate change - Glacier recession • Hydrology • Vulnerability • Peru • Cordillera Blanca

\section{Introduction}

Climate change is significantly affecting high elevation mountain areas across the planet and is occurring much faster than was previously predicted (Bradley et al. 2009; Dyurgerov 2003; IARU 2009; IPCC 2007a; Nogues-Bravo et al. 2007; Stewart 2009; Thompson et al. 2009; Viviroli et al. 2007; WMO 2009). Globally, a significant percentage of humanity is dependent upon the ecological services and water resources that mountain glaciers provide to downstream populations and their rapid recession has widespread implications for future water availability, agricultural production and human vulnerability (Alcamo et al. 2007; Barnett et al. 2005; Barry and Seimon 2000; Fagre et al. 2003; IPCC 2007a; Kundzewicz et al. 2008; Milner et al. 2009; Morton 2007; Orlove 2009; Rosenzweig et al. 2004; Thompson et al. 2006; Viviroli et al. 2007; Xu et al. 2009). Mountains often support complex and deeply interdependent natural and social systems that are extraordinarily sensitive to environmental and social change and provide compelling examples of the rapidly advancing impacts of global warming as they are harbingers of the possible global environmental and social consequences of climate change.

The tropical Peruvian Andes are situated at the confluence of these natural and social changes related to climate change. Between 1970 and 1997, glacial coverage across the country declined by $22 \%$ and average temperatures have increased significantly since 1939 (CONAM 2001; Georges 2004; Kaser and Osmaston 2002; Vuille and Bradley 2000; Vuille et al. 2008b). Because over $80 \%$ of freshwater available for downstream populations and ecosystems of the semi-arid tropics and subtropics originates in mountains, the recession of glaciers in these areas is particularly significant for the social and ecological systems that depend on these vital components of the hydrological regime (Messerli 2001). In Peru, 70\% of the country's 28 million people live along the Pacific Coast, yet only have access to $1.8 \%$ of the total water resources in the country (CONAM 2001). These water resources are seasonally variable as well and during the dry season glacial melt water from mountain catchments provides a vital buffer for the extremely arid desert coastal lowlands (Vuille et al. 2008a). This unique hydraulic interdependence across the Andean escarpment is why Peru is considered to be one of the most vulnerable locations to water stress and climate change related problems in the world and why it will be strongly impacted by the accelerating glacier recession that has been taking place in the high Andean watersheds over the past several decades (Brooks and Adger 2003; Carey 2010; Magrin et al. 2007; Mark 2006; Mark et al. 2010; Painter 2007; Vergara 2009).

This paper presents the findings from research examining the combined relationships between glacier recession, hydrologic change and human vulnerability in the Cordillera Blanca, Peru, the most extensively glacierized mountain range in the tropics. We examine these dynamics in one area of the mountain range, the 
Yanamarey watershed. The linked hypotheses guiding the research are that climate change is accelerating glacier recession in the watershed, hydrological variability is being altered, and that the vulnerability of local household livelihoods is increasing due to new vectors of natural and social change. The paper is structured to systematically examine these relationships and begins with an overview of recent climate change in the Cordillera Blanca and the natural and social context of the region. The next section presents an analysis of multi-decadal measurements of the recession of the Yanamarey glacier and the seasonal to interannual impact of this recession on stream flows in the watershed. The paper then integrates these findings into current vulnerability research efforts and subsequently turns to a short discussion of the human case-study context and research methods utilized in the study. Finally, the paper presents an evaluation of increasing vectors of human vulnerability in the region, which is organized around shifting household access to water resources, the social and natural impacts of increasing weather extremes in the region and the consequences of recent climate-related threats to tourism on household livelihoods. The paper concludes with a synthetic discussion of the research findings.

\section{Glacier recession in the Cordillera Blanca, Peru}

The Cordillera Blanca, Peru, contains the largest concentration of tropical glaciers in the world (Fig. 1). In the early 1970's, 722 glaciers covered more than $723 \mathrm{~km}^{2}$ of the range and accounted for $35 \%$ of Peru's total glacierized area and $40 \%$ of the country's glacial reserves by volume. Nearly $70 \%\left(506 \mathrm{~km}^{2}\right)$ of these glaciers form the crest of the Pacific watershed, which includes the country's highest sum-

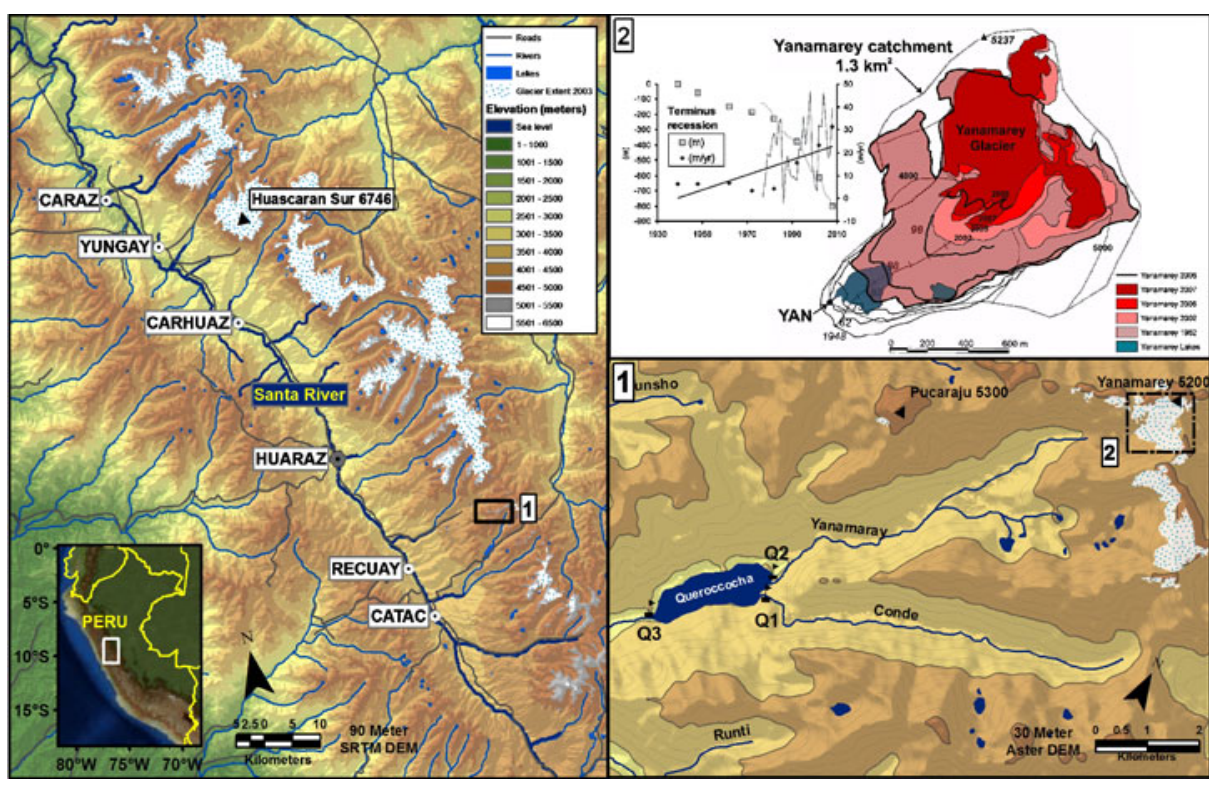

Fig. 1 The Peruvian Cordillera Blanca, the Yanamarey watershed and recession (1948-2008) of the Yanamarey glacier 
mit (Huascaran 6,768 m.a.s.l.), glacial lakes, perennial and intermittent streams, and springs that flow into the Rio Santa valley and eventually the Pacific Ocean (Ames et al. 1989). The climate of the region varies significantly across the steep altitudinal gradients of the Central Andes and the humid highlands are relatively moist compared to the extremely arid desert coastal lowlands. Average precipitation rates in the upper Rio Santa basin, where the Yanamarey case-study is located, range from between 800 and 1,200 $\mathrm{mm} \mathrm{year}^{-1}$ and greater than $80 \%$ of precipitation falls between October and May. Monthly average stream discharge is higher during these months, which reflects the seasonal variability of precipitation typical in the outer tropics (Mark and Seltzer 2003). Average annual temperatures range from $0^{\circ} \mathrm{C}$ to $9^{\circ} \mathrm{C}$ with an annual range that is much smaller than the diurnal variation (Kaser et al. 1990).

Glaciers in the Cordillera Blanca have been rapidly receding over the past several decades. Recent studies indicate that glacier coverage has declined by more than $25 \%$ since 1970 , average temperature has increased $0.35-0.39^{\circ} \mathrm{C} /$ decade between 1951 and 1999 and that these changes are accelerating in a nonlinear fashion (Bradley et al. 2009; Mark 2002; Mark and Seltzer 2005; Racoviteanu et al. 2008; Urrutia and Vuille 2009; Vuille et al. 2008b). Glacial melt water is critical to the diverse ecosystems of the region and supports unique landscape mosaics that are the result of millennia of complex biophysical, ecological and human interaction (Young 2009). At least ten biological life zones have been identified in the region, which include subtropical and tropical zones, and puna, or high alpine tundra (Pulgar Vidal 1981). The high watersheds support grassland ecosystems and fragmented concentrations of trees and shrubs along watercourses and the edges of the highest valleys. More than 50 groundcover and 18 tree and shrub species have been identified in the region (including four Polylepis species and the rare Puya raimondii) as well as more than 70 different animal species (CCC 2006).

The retreating glaciers of the Cordillera Blanca have supported the activities of Andean societies for millennia (Pearsall 2008; Pozorski and Pozorski 2008). Currently, the 267,000 human inhabitants of the upper Rio Santa, which is often referred as the Callejón de Huaylas, are distributed across hundreds of small rural settlements and more than half of the population is concentrated in major urban and peri-urban clusters along the Rio Santa, including the cities of Caraz $(13,000)$, Yungay (8,000), Carhuaz (7,200), Recuay $(2,700)$, Catac $(2,400)$, and in the city of Huaraz $(96,000)$, which is the largest urban center in the region and the capital of the Department of Ancash (INEI 2007; Mark et al. 2010).

Historically, glaciers in the Cordillera Blanca have provided continual melt water to sustain river discharge through droughts and the dry-season (Mark et al. 2005). Inhabitants of the region have become increasingly dependent on this perennial availability of water resources for human consumption and a host of economic activities, including natural resource based livelihood activities that principally revolve around livestock and seasonal agriculture as well as agroforestry, tourism services, dairy production and artisanal crafts. Recent economic and social change has further intensified this reliance on water resources. While nearly $50 \%$ of the population of the region lives in conditions of extreme poverty and most small-scale livelihood activities are directed towards basic survival, since the late 1990's large-scale agricultural production activities have been shifting towards water intensive, irrigated, high-value crop production in the Callejón de Huaylas and along the arid costal shelf 
in new agro-export zones such as Chavimochic (INEI 2007; Painter 2007). A number of Peruvian and transnational mining companies have also begun operations in the region as well, which now account for approximately $40 \%$ of all economic production in the region (BCRP 2009; Bebbington and Bury 2009; Bury 2005). Finally, the watershed is a critical source of water for several hydroelectric power plants that currently account for approximately $10 \%$ of the country's hydroelectric capacity (MEM 2008).

These recent social and economic shifts have placed significant new pressures on water resources in the region, while at the same time that glacial recession rates have been increasing. Recent research suggests that once glacial replenishment begins to disappear, glacial fed rivers and streams will have smaller dry season flows and display increasing variability (Francou and Coudrain 2005; Juen et al. 2007). The combined nature of these changes could lead to even further water stress throughout the region, which would have significant social and economic consequences.

\section{Observations of physical change: quantifying Yanamarey glacier recession and hydrologic impact}

The Yanamarey glacier and Querococha watershed (See Fig. 1) comprise one of the most studied sites of glacier hydrology in the Peruvian Cordillera Blanca. Regular observations of glacial extent and climate variables associated with hydropower production by the Huaraz-based Peruvian Office of Glaciology and Lake Security date back to the 1970s (Carey 2005). While observations prior to this period are rare or discontinuous for the region, compilations of historical glacier maps and photographs quantify glacier mass balance changes over time (Ames et al. 1989; Georges 2004; Kaser et al. 1990; Kinzl 1942; Kinzl et al. 1964; Morales Arnao and Hastenrath 1998). A program of routine surveying was established in 1968, and four target glaciers, including Yanamarey, were selected to monitor the magnitude of changes to these frozen reservoirs, providing a particularly important geographic database (Ames 1998; Francou et al. 1995).

The Yanamarey glacier was visited annually in May and September, at the end of the wet and dry seasons respectively, beginning in 1998. A network of mass balance stakes were maintained, mostly in the lower ablation zone of the glacier. The amount of stake exposed was measured during the biannual visits, and these data were combined with snow pit measurements of accumulation, which allowed a net mass balance to be generalized for the entire glacier. Topographic maps of the glacier surface were made from terrestrial surveys in 1973, 1982, 1988, and 1995, and by aerial photogrammetry for 1948 and 1962. Between 1981 and 1995 totalizing rain gauges recorded precipitation, and temperature and relative humidity were measured with a wind-up analogue thermograph located next to the leftlateral terminus. About $8 \mathrm{~km}$ downstream from the Yanamarey glacier, a weather station and stage (stream height) recording discharge station were installed in 1965 at the effluent of Querococha, the second largest lake in the Cordillera Blanca. The mechanical float and recording drum instrumentation to record stage proved surprisingly robust, and regular measurements of discharge (i.e., the volume of water flowing per unit time) provided a rating curve that was updated and maintained until the Office of Glaciology and Lake Security was closed in the late 1990's, when 
Electro Peru privatized the hydroelectric production at Cañon del Pato and closed the Huaraz office of glacier-hydrology operations. A review of discharge and climate at Querococha provided an insight into the nature of ENSO impact on the glaciers (Francou et al. 1995). ${ }^{1}$ Monthly observations for a complete hydrological year were made by B. Mark between 1998 and 1999, and were used to estimate the hydrological balance at the Yanamarey glacier lake outlet and relative contribution of glacier melt to Querococha (Mark and Seltzer 2003). Subsequent observations of glacier recession and glacier lake discharge have been maintained by a renewed Office of Glaciology and Water Resources (UGRH) under INRENA, which is now located within the new National Water Authority (ANA). New instrumentation includes continuous data logging of climate variables and discharge from the proglacial lake at YAN (Fig. 1).

\subsection{Yanamarey glacier recession and climate sensitivity}

The terminus of the Yanamarey glacier has receded over $800 \mathrm{~m}$ since the earliest photogrammetry position of 1948, and it is continuing to recede rapidly (Fig. 1, inset). While the terminus had some small advances and the annual rate of recession is variable, the late-twentieth century featured dramatic overall glacier recession, consistent with other tropical glaciers (Kaser 1999) and pervasive wastage of glaciers globally (Dyurgerov 2003). After 1970, decadal-average recession rates define a highly significant $(p<0.005)$ acceleration of $8 \mathrm{~m} \mathrm{decade}^{-2}$. The rate averaged over the last 6 years is greater than $30 \mathrm{~m} \mathrm{year}^{-1}$ (See Fig. 1). Such strong and persistent recession is consistent with glaciers throughout the Cordillera Blanca that have been receding since the end of the Little Ice Age (Georges 2004). Accelerated recession rates have also been observed in other Andean locations, which imply a high degree of glacier sensitivity to interannual climate variability (Brecher and Thompson 1993; Casassa et al. 1998; Juen et al. 2007; Thompson 2000). However, deciphering the impact of glacier changes on water resources requires accounting for melt water volume fluctuations measured directly or captured by the basin hydrologic balance (Kaser et al. 2003; Mark 2006).

The relatively extensive history of observations on the Yanamarey glacier permitted a quantitative assessment of mass-loss rates (Hastenrath and Ames 1995a), and formed the basis for sensitivity studies of the climatic forcing and hydrologic impact (Hastenrath and Ames 1995b). The semi-regular glacier mass balance and surface velocity measurements from surveys of the stake displacement allowed for a mass flux to be computed. A combination of increased humidity, cloudiness, and increased temperature were determined to be the factors forcing the twentieth century mass loss. These climatic trends would be consistent with anthropogenically forced global warming. Projecting from the computed average mass-loss rate, the receding glacier was predicted to disappear within 50 years. Moreover, when all other mass fluxes in and out of the glacier watershed were accounted for, the authors concluded that half of proglacial lake discharge (YAN in Fig. 1) had to come from net glacier melt. However, seasonal differences in the glacier melt supply were not computed, and

\footnotetext{
${ }^{1}$ The monthly operations ended just before the 1998 El Nino event, the largest in the twentieth century.
} 
these differences are important to understand given the large contrast between wet and dry season precipitation supply.

\subsection{Seasonal glacier melt water contribution to stream flow}

Tracing the inter-seasonal variations in glacier melt water contribution, not only at the glacier outlet, but downstream where human society utilizes stream flow, requires various hydrologic methods. These include detailed field observations, stream gauging, and hydrochemical modeling over successively larger watershed scales. Starting at the upper, first-order glacier watershed defined by YAN, monthly measurements of discharge, precipitation and hydrochemistry over the 1998-1999 hydrological year (measured between 1 July and 30 June) allowed for the seasonal melt contribution to stream discharge to be calculated by Mark and Seltzer (2003). Incorporating a two-component mixing model based on the chemical properties of water from different sources (i.e. glacier melt and precipitation runoff), the total annual contribution of glacier melt to YAN was computed to be on the same order of magnitude as the previous estimation from decadal observations (45 $\pm 5 \%$ ). However, during the dry season months, glacier mass loss accounted for up to $100 \%$ of stream flow.

Further downstream, the glacier-fed stream (Q2) from YAN and the neighboring glacier valley reaches a confluence with a stream from a non-glacierized watershed (Q1) at Querococha, providing a site to estimate end-member mixing at a larger spatial scale. Monthly measurements of hydrochemistry at each inflow and the combined effluent from Querococha (Q3) (Fig. 1) were averaged over the entire hydrological year. This yielded a chemical mixing estimation that 35\% of Q3 discharge originated from Q2 (Mark et al. 2005). Proportionately, this meant 10-20\% of annual Q3 was comprised of glacier melt. Since the Q3 watershed has the same magnitude of glacierized area $(\sim 10 \%)$ as the entire Callejón de Huaylas watershed capturing the Rio Santa drainage of the Cordillera Blanca, it suggests that this same estimate of relative glacier melt contribution might apply to this larger spatial scale.

More recently, estimates of relative hydrologic end-member contributions have been improved using a three component hydrochemical mixing model to show seasonal differences (Baraer et al. 2008). Results for the year 1998-1999 at Q3 suggest that glacier melt water represented $25 \%$ of the annual outflow while the remainder was comprised of both short residence time sources (mainly surface runoff) and longer residence time sources (mainly groundwater), respectively contributing $60 \%$ and $15 \%$ of the annual Q3 discharge. When this model analysis is applied only to the 1998 dry season (June, July and August), the relative contributions of end members describe another hydrological situation whereby glacial melt water comprises $50 \%$, longer flows $47 \%$ and the shorter flows only 3\% of the Q3 discharge.

Although subsequent monthly sampling of hydrochemistry has not been carried out, the low flow hydrochemistry has been measured annually at different sampling points along the basin since 2004, giving some insight into the inter-annual variability of low flow end-member mixing. The refined mixing model suggests that between 2004 and 2008, annual glacier melt water contribution downstream is variable, and that groundwater contributions predominate (Baraer et al. 2009). For example, at the Q2 sample site, glacier melt reached a maximum relative contribution of $54 \%$ in 2005 and a minimum of $24 \%$ in 2008 . The average Q2 discharge was approximately 
$35 \%$ glacier melt, implying that groundwater contributes over half of the dry-season discharge.

\subsection{Interannual changes in hydrology and climate}

While measurements of discharge and precipitation have not been maintained continuously, the available monthly observations collected in the Yanamarey glacier catchment provide an opportunity to compare decade-scale changes in the seasonal glacier hydrology since the measured hydrological balance year (1998-1999). During this year, monthly measurements of inputs (total precipitation) and outflows (discrete monthly discharge from YAN) permitted a simplified hydrologic mass budget to describe glacier storage changes. Because monthly measurements of precipitation exist for the prior decade (1980-1991), the relationship between the seasonal hydrograph of monthly discharge can be related to precipitation. Likewise, availability of monthly precipitation and continuous discharge data beginning with the 2001 installation of automated discharge and precipitation recording devices at YAN give another period of model comparison (2001-2008).

The budget model assumes that the total volume of water discharging from the catchment is equal to the volume of water entering the catchment plus a change in storage. This model can be expressed to isolate the glacial melt water contribution to stream discharge as the change in the glacial storage term $(\Delta$ storage):

\section{$\Delta$ storage $=$ precipitation - discharge}

It is assumed that the primary outflow consists of the total discharge leaving the proglacial lake at YAN, from the stage recorder, whereas the only input is precipitation into the watershed. Precipitation was measured from a totalizing gauge located at the southern glacier margin (4,764 m.a.s.l.) during monthly visits to the site when the stream stage recording data were also retrieved. A uniform distribution of precipitation falling over the $1.35 \mathrm{~km}^{2}$ Yanamarey catchment is assumed.

As shown in Fig. 2 the mass balance is no longer positive, even during the height of the wet season of 1998-1999. Discharge has increased, and has become more coincident with maximum precipitation. Furthermore, when the water balance terms are taken as annual totals (Fig. 3), the rising trend of total annual discharge shows a highly significant $(p=0.001)$ anti-correlation with annual loss of glacier storage, while there is no trend in total annual precipitation. Average storage changes in 1998-1999 indicated that glacier melt from Yanamarey contributed $35 \pm 10 \%$ of the annual discharge. The error estimate accounts for precipitation and runoff uncertainty (Mark and Seltzer 2003). Over the more recent interval, the total loss of glacier storage has not shown uniform change, but varied both in absolute magnitude and relative percentage of discharge. The average relative melt contribution estimate is $59 \pm 10 \%$ of YAN discharge over the last 7 years (2001-2008), with the maximum relative contribution (67\%) occurring during the lowest absolute flow (2005).

Despite inherent sampling limitations, our physical measurements of changes to the Yanamarey glacier and downstream hydrology represent a relatively unprecedented quantification of tropical glacier-hydrologic transformations over time. Our extensive Yanamarey data set features discrete periods of monthly observations to explore changes in seasonality. Comparisons of area-normalized precipitation 


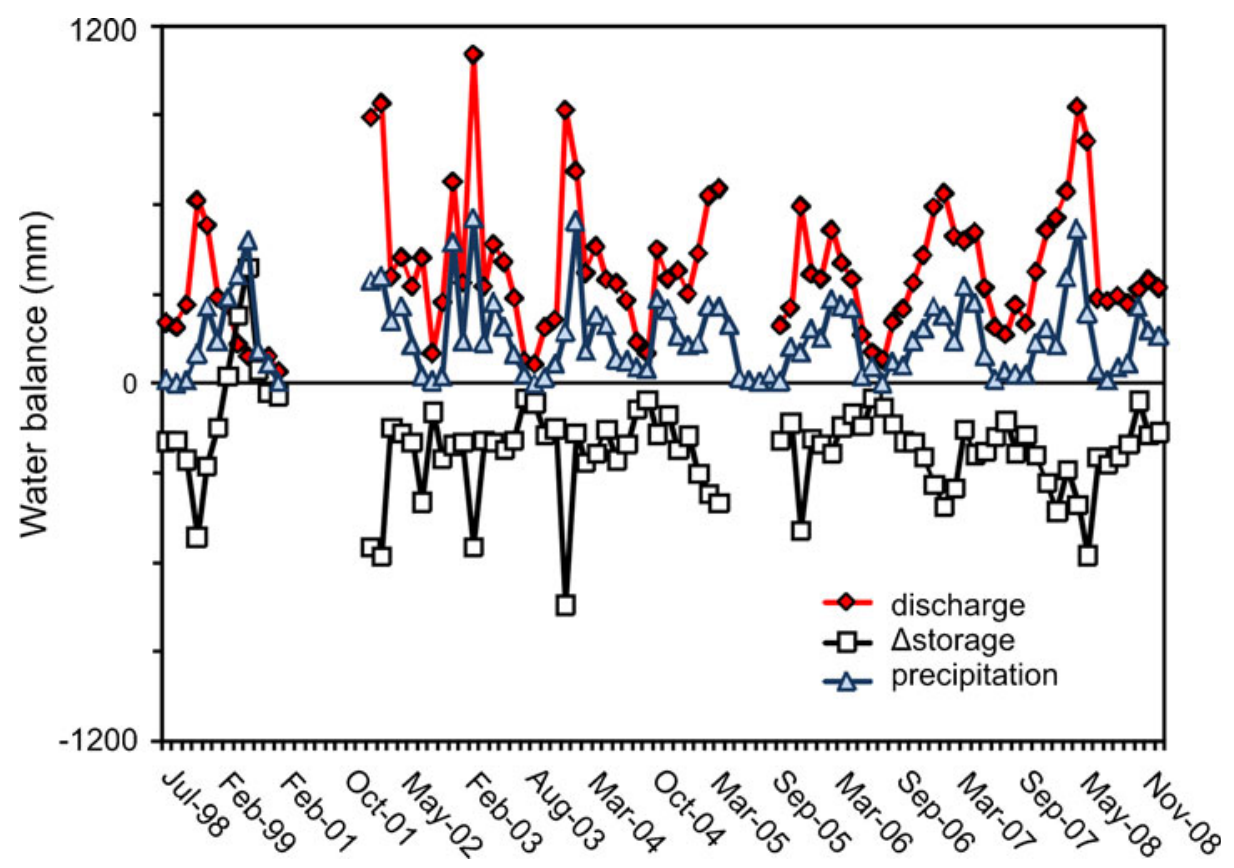

Fig. 2 Monthly hydrologic mass balance at YAN, showing constant release of glacier storage (negative $\Delta$ storage) since 2002, as well as higher peak discharge more coincident with maximum precipitation. All terms in (millimeters) as normalized for glacier watershed surface area $\left(1.35 \mathrm{~km}^{2}\right)$

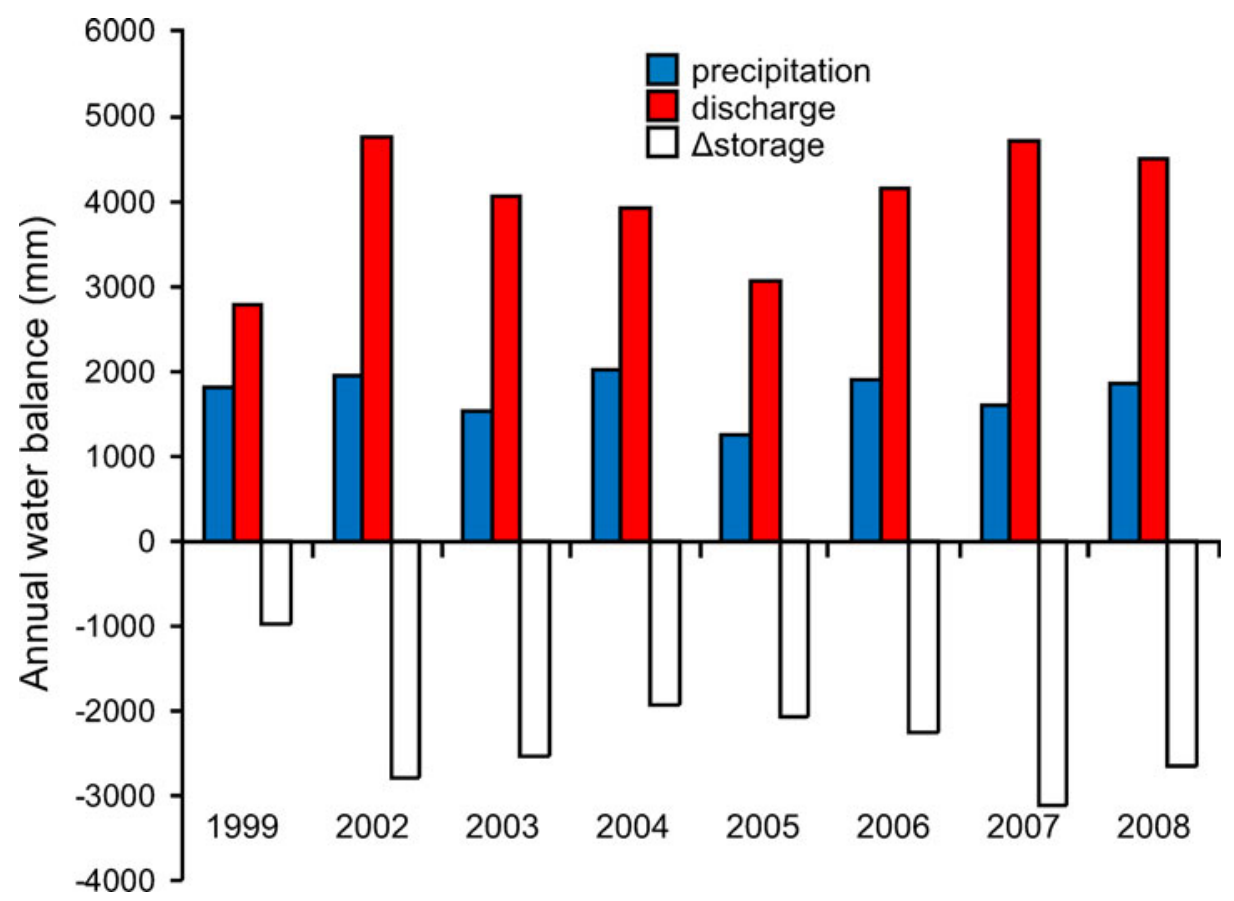

Fig. 3 Annual hydrologic mass balance at YAN computed as sum of monthly terms shown in Fig. 2 


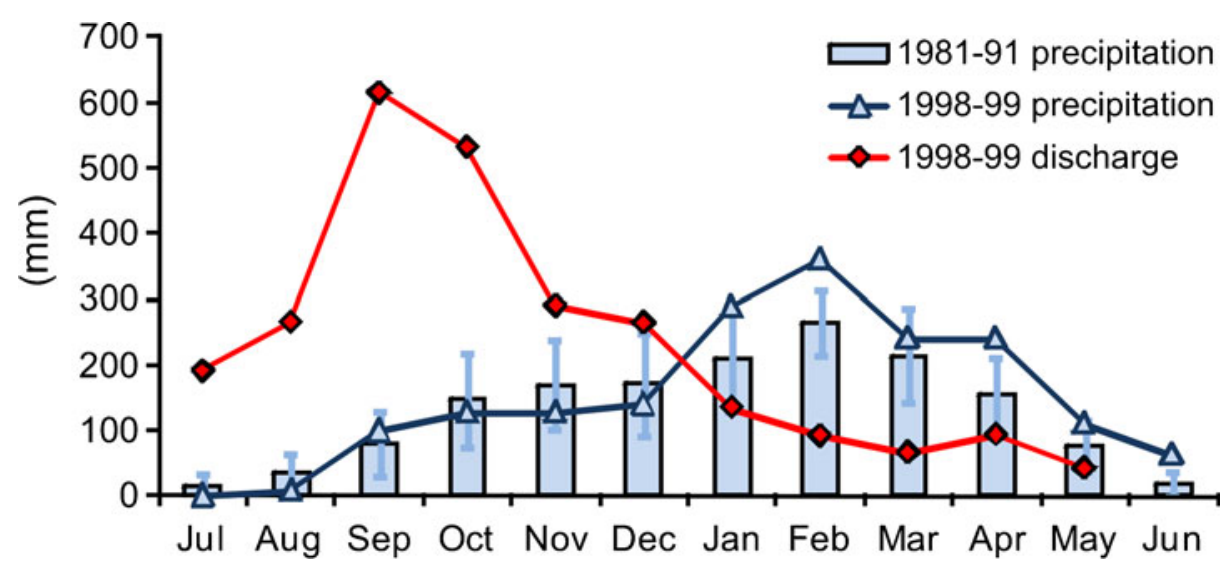

Fig. 4 Composite graph showing annual march of monthly total precipitation and discharge at YAN measured monthly during a single hydrological year (July 1998-June 1999). The monthly total precipitation is shown both as averaged values over the 1981-1991 interval (shown in light blue bars with 1 standard deviation range) and also as the measured values for the same single 1998-1999 hydrological year (dark blue line with triangles). Monthly discharge values shown with red diamonds joined by red line

over the two near-decadal spans of measurements with the 1998-1999 reconstructed hydrograph data (Fig. 4) and the measured 2003-2008 data (Fig. 5) indicate a possible change in seasonality of available water flowing from YAN. The YAN discharge in 1998-1999 reached a maximum during September, before the precipitation maximum in February. Yet by 2003-2008, total discharge is enhanced, with maximum precipitation coincident with maximum discharge in January. Without additional data before 1998, it is difficult to determine if the 1998-1999 data are anomalous. However, because the monthly 1998-1999 precipitation was not distinct from the 1981-1991 decadal average, is appears more likely that a change in mass balance

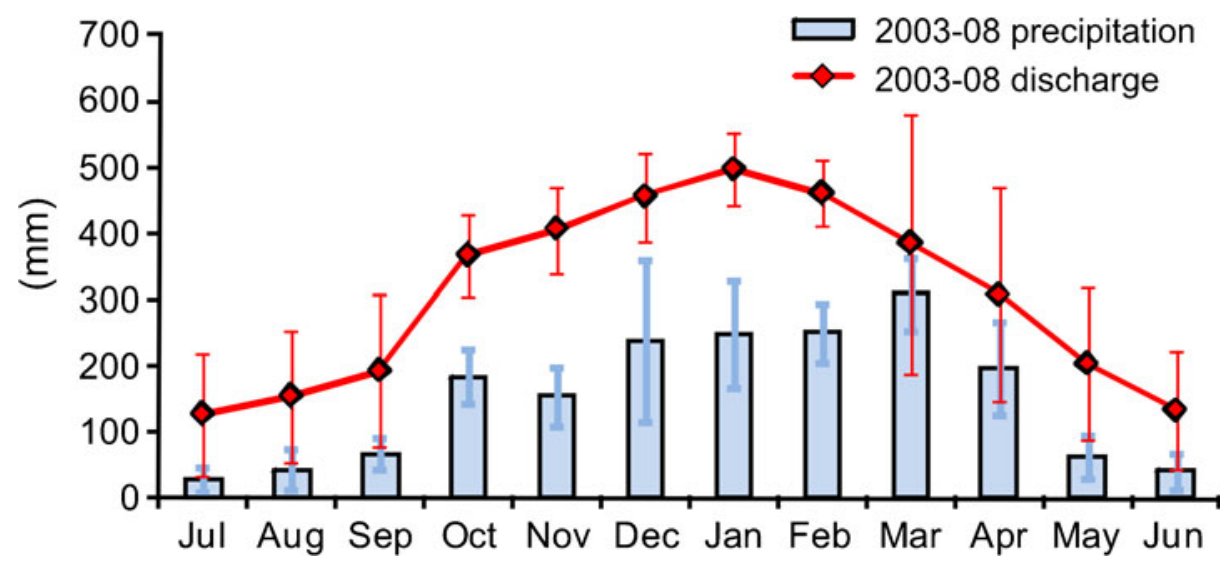

Fig. 5 Composite graph showing monthly total precipitation and discharge for YAN, averaged over 2003-2008 range of measurement; error bars represent 1 standard deviation range 
seasonality explains the shift in discharge seasonality. The constantly negative mass balance of the glacier could have both increased discharge and also made the contrast between dry and wet season discharge higher in more recent time.

Over the 2003-2008 interval, the Yanamarey glacier has lost considerable mass, and the rate of loss continues to accelerate. The hydrological balance results suggest that the Yanamarey glacier could have lost 22.5 million cubic meters of ice over this time, resulting in shifts in seasonal hydrology.

\section{Bridging traditions: evolving approaches to vulnerability science}

The changes taking place in the Yanamarey watershed illustrate how, in part, anthropogenically-induced global climatic change is fundamentally transforming the biosphere. Human vulnerability to these changes has become an important focus for an array of researchers and institutions concerned with environment-society relations, global change dynamics, and sustainability science (Adger 2006; IPCC 2007b; Turner et al. 2003). Vulnerability, as defined by the Intergovernmental Panel on Climate Change (IPCC 2007b), refers to the "degree to which a system is susceptible to, and unable to cope with, adverse effects of climate change" (p. 15). Much recent work on vulnerability focuses on the exposure, sensitivity and resilience of human systems to various forms of climate-related risk and argues that the strengthening of adaptive capacity and livelihood security must be a central concern of development efforts (UNDP 2007; USAID 2007; Vergara 2009; WorldBank 2008). Vulnerability research has conceptual roots in risk and natural hazards studies focused on the prediction and monitoring of specific and uncertain biophysical threats, the identification of thresholds of harm, and the engineering of responses to impacts (Burton et al. 1978; White 1973). Theoretical approaches from political economy and political ecology have also contributed significantly to the development of vulnerability research by emphasizing the importance of underlying socioeconomic, cultural and institutional factors that produce varying levels of resource access and risk exposure among distinct groups as well as differential abilities to respond to the impacts of hazards (Bohle et al. 1994; Hewitt 1983; Peet and Watts 2004).

Studies integrating important elements of both the natural hazards and political economic frameworks have become increasingly common as vulnerability research has evolved to address growing concerns about how natural disasters and climaterelated risks intersect with other global change processes. These hybrid approaches include the pressure-and-release model, which describes disasters as the product of natural events occurring in specific social, political, and economic environments that generate differential levels of vulnerability (Blaikie 1994; Wisner et al. 2004), the analysis of cases of "double exposure" in which human systems are subject to impacts and events linked to climate change as well as to the transformative forces of globalization (Leichenko and O'Brien 2008), and as vulnerability to multiple exposures, or combinations of biophysical, political, economic and institutional conditions (Eakin 2006; Eakin and Wehbe 2009; Liverman 1990). This increasing attention to interacting causal factors highlights vulnerability's multi-faceted and dynamic nature as well as the need for detailed analyses of specific social-ecological systems and their linkages to global change processes across scales (Clark et al. 2000; Cutter 2003). 
Vulnerability research has emerged across a range of disciplines including global change and sustainability science, geography, development studies and disaster management. Each of these disciplines has developed its own conceptual models and methodological approaches, which has frequently resulted in confusion and disagreement over key concepts and definitions and has created challenges for researchers seeking to generate conclusions from the findings of these studies (Adger 2006; Cutter 1996). Recent research bridges these disciplinary divides through clarifications of frequently used terms and expanded conceptual frameworks (Füssel 2007; Polsky et al. 2007; Thomalla et al. 2006), and focuses on the critical importance of interdisciplinary perspectives, diverse methodological approaches, and attention to specific contexts and outcomes in addressing the complexity of vulnerability (Eakin and Luers 2006; Turner et al. 2003; Turner and Robbins 2008).

This article builds upon these emerging trends in vulnerability studies through intensive interdisciplinary engagement utilizing methods and theoretical approaches from glaciology, hydrology, geochemistry, geographic information science, sustainability science and environment-society and development studies. Our analysis of human vulnerability to climate change and hydrologic variability in the central Peruvian Andes integrates analyses of biophysical changes with an in-depth, multiscalar investigation of the underlying socioeconomic, political and institutional conditions that contribute to significantly varying degrees of risk exposure in different segments of the population. Specifically, we evaluate the ways in which shifting hydrologic regimes in the region are enhancing the vulnerability of local populations by focusing on household access to resources and livelihood production. Our selection of water resources as the key nexus for the biophysical and social components of the research reflects both the magnitude of changes taking place in these resources in the Andes as well their critical importance to a variety of local livelihood production strategies.

Our analysis also contributes to research focused on the influence that climate change has had on the historical development of the region as well as on the emergence of new political and economic conflicts over access to and governance of natural resources. Research focusing on these issues highlights the historical role of changing climate patterns for the region (Dillehay and Kolata 2004) as well as the potential for climate change to exacerbate conflicts over water resources at the regional scale (Barry and Seimon 2000; Bradley et al. 2006; Orlove et al. 2008), in Ecuador (Rhoades et al. 2006) and for large urban centers (Francou et al. 1995; Painter 2007). In the Cordillera Blanca, Young and Lipton (2006) provide an overview of the impacts of climate change on glaciers, livelihoods, and governance and recent studies focus more specifically on the history of glacier-related hazards (Carey 2010; Hegglin and Huggel 2008).

Overall, we seek to bridge current vulnerability research efforts by focusing on the linkages between biophysical and social change in a single watershed in the Cordillera Blanca in order to evaluate their impacts on the livelihood security of local residents. Our grounded and detailed analysis of the effects of glacial recession and climatic variability on local household livelihoods provides for the generation of a broad set of empirical data that illustrates how household vulnerability to shifting natural resources is distributed across the spatial and sociocultural landscape of the study area. In addition, we emphasize the speed at which human vulnerability is being affected in the region and the potential consequences of glacier 
recession and climate change for the livelihood activities that households currently pursue.

\subsection{Case study community context and methods}

The inhabitants of the Yanamarey region are concentrated in the town of Catac and several dozen small household clusters distributed along the high mountain watersheds. In 1965 the town of Catac was recognized as a municipality under Peruvian law, but the lands surrounding the town and many of its 2,200 inhabitants belong to one of Peru's 5,818 peasant communities, the Campesino Community of Catac (INEI 2006). Campesino Communities have been granted special status under Peruvian law as native descendents of Peru and they often engage in communal natural resource management activities and are afforded unique rights of selfgovernance (CEPES 1996; Del Castillo 2005). These organizations currently control nearly $39 \%$ of the land in Peru, most of which is located in the rural high mountain areas of the country (PETT 2002).

While Catac is just one of 345 Campesino Communities in the Department of Ancash, it is one of the most organized and has some of the largest landholdings as it controls approximately 66,000 ha of land in 18 high valleys of the Santa River basin. The community traces its historical roots to two Incan settlements (ayllus), but it has only been formally recognized by the Peruvian state for less than a century. In 1941 community leaders secured recognition as an independent community and in 1963 they reclaimed lands seized by hacienda owners under the land reform of President Belaunde. ${ }^{2}$ In 1975 the Peruvian government created Huascaran National Park, which was superimposed on $62 \%$ of the community's territories and accounts for $12 \%$ of the total area of the park (CCC 2006). While the community still has access to lands in the park for grazing and other uses (which are often limited by park management protocols) based on historical precedent, the designation of community lands as part of the National Park has been a source of constant conflict between the community's approximately 1,000 members, park representatives and the national government. Disputes over access to and management of natural resources, territorial development, conservation and tourism have all been persistent focal points around which political and economic relations have converged. ${ }^{3}$

In order to evaluate how climate change induced glacier recession is affecting the vulnerability of livelihoods in the region and as a way of linking the social and geophysical components of our interdisciplinary investigation, we conducted casestudy research in the town of Catac, in small neighboring settlements and among the members of the Campesino Community of Catac. Beginning in 2006 we conducted several sets of key interviews and household surveys in the Yanamarey watershed in order to examine the linkages between glacier recession, hydrologic shifts and

\footnotetext{
${ }^{2}$ In 1993, Catac was recognized formally as a Campesino Community under the Peruvian Constitution during Alberto Fujimori's presidency. Since then many of the lands belonging to the community have been granted titles by the Peruvian Ministry of Agriculture (PETT 2002).

${ }^{3}$ Young and Lipton (2006) provide a much more extensive and thorough coverage of Huascaran National Park and larger regional issues than we can provide in our discussion.
} 


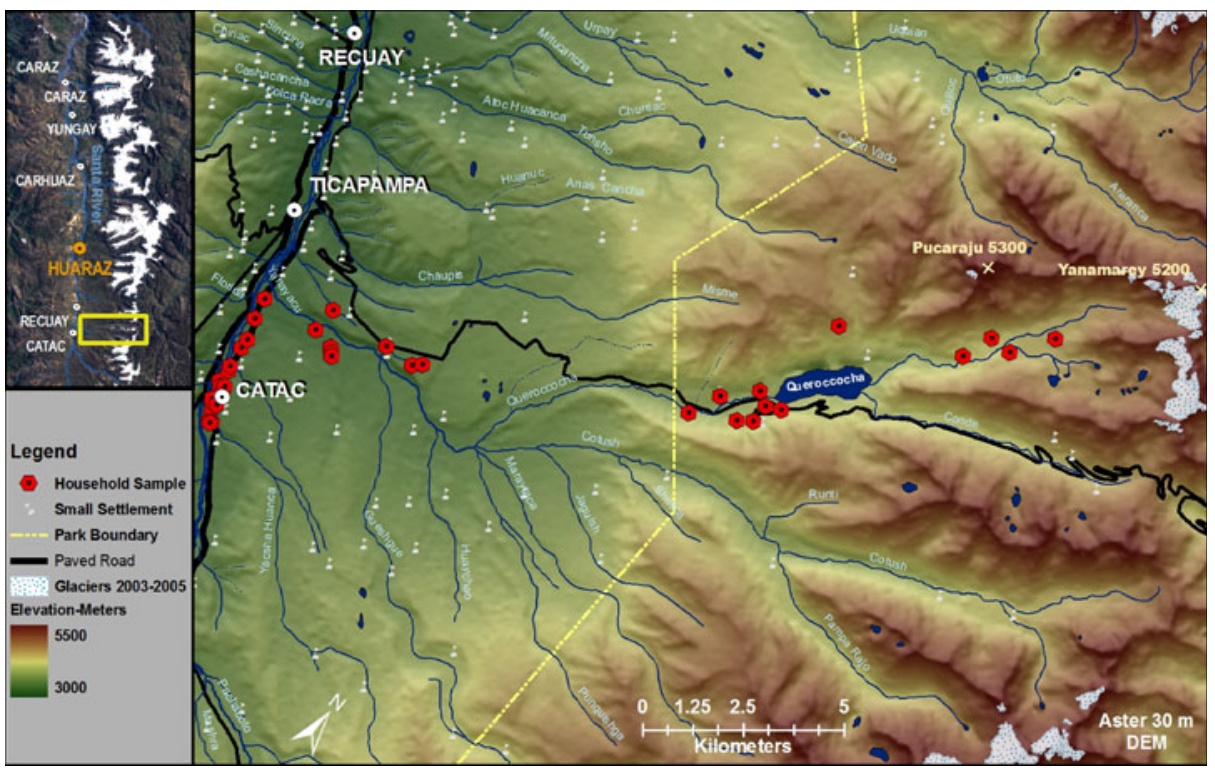

Fig. 6 Location of the Catac case study area and household sample distribution

livelihood practices and to assess the vectors through which vulnerability might be increasing.

The research design for the project is based on a purposive case-study of the Yanamarey catchment. Yanamarey is one case-study example from a multi-year comparative research project that is designed to assess how social and environmental dynamics are changing across a range of watersheds with different glacierized percentages. This methodological framework is intended to provide for a maximum distribution of observable natural and social impacts related to recent glacier recession in the region (King et al. 1994). The Yanamarey watershed was selected in order to investigate the nature of impacts taking place in a catchment with little glacial cover remaining and in order to illustrate the temporal character of these changes in a comparative fashion across all of the case study watersheds. We refer to this as a "space for time swap" selection strategy (Mark et al. 2010).

In 2007 we conducted a preliminary set of key interviews and household surveys to evaluate human perceptions of ecological change in the region and the impacts of recent glacier recession on resources that households depend upon for livelihood production. We then designed a sampling method to limit potential selection biases and in 2008 we conducted a more extensive set of key interviews and semi-structured household surveys utilizing a stratified random sample drawn from the city of Catac and 12 small neighboring settlements (See Fig. 6). ${ }^{4}$ The surveys were then field tested and questions were carefully worded to avoid respondent prompting

\footnotetext{
${ }^{4}$ The spatially-based random household sampling strategy utilizes a GIS polygon-based technique. The polygon encompasses all of the land in the Yanamaray basin and the sample was stratified to accommodate the uneven distribution of urban and rural households along the vertical axis of the watershed.
} 
Table 1 Case study demographic, water and land resource summary

\begin{tabular}{|c|c|c|c|c|c|}
\hline $\begin{array}{l}\text { Case study sample } \\
\text { demographic summary }\end{array}$ & & $\begin{array}{l}\text { Household water } \\
\text { resources summary }\end{array}$ & & $\begin{array}{l}\text { Household land } \\
\text { resources summary }\end{array}$ & \\
\hline $\begin{array}{l}\text { Total case study } \\
\text { area population }\end{array}$ & 3,249 & $\begin{array}{l}\text { Percentage of } \\
\text { households with } \\
\text { access to potable } \\
\text { water }\end{array}$ & $68 \%$ & $\begin{array}{l}\text { Percentage of } \\
\text { households who } \\
\text { own or have access } \\
\text { to land resources }\end{array}$ & $90 \%$ \\
\hline $\begin{array}{l}\text { Total households in } \\
\text { sample population }\end{array}$ & 40 & $\begin{array}{l}\text { Percentage of } \\
\text { households with } \\
\text { sanitary services }\end{array}$ & $54 \%$ & $\begin{array}{l}\text { Average number } \\
\text { of parcels per } \\
\text { household }\end{array}$ & 1.8 \\
\hline $\begin{array}{l}\text { Average sample } \\
\text { household } \\
\text { population }\end{array}$ & 5 & $\begin{array}{l}\text { Percentage of } \\
\text { households who } \\
\text { stated they did } \\
\text { not have enough } \\
\text { water for human } \\
\text { consumption }\end{array}$ & $0.05 \%$ & $\begin{array}{l}\text { Average size of land } \\
\text { parcel (hectares) }\end{array}$ & 0.37 \\
\hline $\begin{array}{l}\text { Total sample } \\
\text { population }(5.5 \% \text { of } \\
\text { total population) }\end{array}$ & 181 & $\begin{array}{l}\text { Percentage of } \\
\text { households with } \\
\text { access to irrigation }\end{array}$ & $63 \%$ & $\begin{array}{l}\text { Average sum of } \\
\text { individual household } \\
\text { land resources } \\
\text { (hectares) }\end{array}$ & 0.83 \\
\hline $\begin{array}{l}\text { Average age of } \\
\text { respondents }\end{array}$ & 47 & $\begin{array}{l}\text { Percentage of } \\
\text { households who } \\
\text { stated they did } \\
\text { not have enough } \\
\text { water for irrigation }\end{array}$ & $26 \%$ & $\begin{array}{l}\text { Percentage of } \\
\text { respondents that } \\
\text { practice land } \\
\text { fallowing }\end{array}$ & $83 \%$ \\
\hline \multicolumn{6}{|l|}{$\begin{array}{l}\text { Gender of } \\
\text { respondents }\end{array}$} \\
\hline Male & $35 \%$ & & & & \\
\hline Female & $65 \%$ & & & & \\
\hline
\end{tabular}

biases. The survey contained 46 questions to evaluate household access to and use of resources and to assess how recent environmental change might be affecting household livelihood activities. The survey questions included 32 structured and 18 open-ended questions grouped in sections that include environmental change, land resources, agricultural activities, personal data and social resources. All open-ended questions were transcribed and entered into a qualitative database for analysis and the structured questions were coded across 234 variables for a total of 9,360 possible data points. Table 1 presents a summary of the demographic characteristics of our case-study sample population and a brief descriptive analysis of household access to and utilization of water and land resources, which will be discussed further in the subsequent sections.

\subsection{Livelihoods and new vectors of vulnerability}

Households in the Catac region have historically been dependent upon access to natural resources, ecosystem services and environmental conditions such as glacialfed streams and rivers, precipitation, regular season shifts between wet and dry seasons, moderate temperature variation, endemic vegetative species and soil systems to produce their livelihoods. Through access to these resources, households have 
predominantly pursued a mix of agricultural and pastoral activities, which are often vertically dispersed across altitudinal zones, spatially concentrated around access to water resources and embedded within complex networks of communal and private land management practices. However, because most of the communal lands of Catac are located at elevations above $4,000 \mathrm{~m}$, grasslands dominate the landscape as most food crops are difficult to cultivate. Consequently, while many households engage in agricultural activities, livestock production is the most important livelihood pursuit for the majority of households. Cattle and sheep are the most important livestock for households and the Campesino Community has pursued cattle improvement strategies with some success as it has won many awards in regional livestock competitions. Households also engage in several other types of livelihood activities, which often depend on access to extra-communal political, economic and social networks in addition to natural resources. Table 2 summarizes the most prevalent livelihood activities in the case-study communities.

Though households pursue a variety of strategies in their livelihood activities, the cumulative results of their efforts are frequently insufficient to meet even basic household needs. Catac has some of the highest levels of household poverty in the region due to the scarcity of agriculturally productive soils and poor climatic conditions linked to the high elevation of the region. Consequently, the livelihood activities that many households pursue are primarily directed towards survival and auto-consumption. This is a critical factor for any attempt to evaluate new vectors

Table 2 Major livelihood activities in Catac

\begin{tabular}{|c|c|c|}
\hline Activity & $\begin{array}{l}\text { Prevalence } \\
(\text { of total } n) \\
(\%)\end{array}$ & Description and variety ( $\%$ of respondents) \\
\hline Livestock & 85 & $\begin{array}{l}\text { Cattle }(74 \%) \text {, sheep }(71 \%), \text { horses }(47 \%), \\
\text { guinea pigs }(35 \%) \text { burros }(18 \%) \text { pigs }(67 \%)\end{array}$ \\
\hline Agriculture & 68 & $\begin{array}{l}\text { Tubers: potatoes-Solanum tuberosum }(63 \%) \text {; } \\
\text { oca-Oxalis tuberosa, olluco-Ullucus tuberosus }(41 \%) \text {; } \\
\text { mashua-Tropaeolum tuberosum }(15 \%) \\
\text { Grains: wheat-Triticum aestivum }(52 \%) \text {; } \\
\text { barley-Hordeum vulgare }(44 \%) ; \\
\text { oats-Avena sativa }(7 \%) \text {, } \\
\text { quinua-Chenopodium quinoa }(4 \%) \\
\text { Beans-Vicia faba }(15 \%) \\
\text { Tarwi-Lupinus mutabilis }(4 \%) \\
\text { Corn-Zea mays }(1 \%)\end{array}$ \\
\hline Agroforestry & 68 & $\begin{array}{l}\text { Eucalyptus-Eucalyptus globulus }(78 \%) \text {; } \\
\text { uses-firewood, construction, wind break } \\
\text { Quenual-polylepis }(33 \%) \text {; } \\
\text { uses-firewood, construction, planting } \\
\text { Other: pine-Pinus radiata; Capuli-Prunus serotina, } \\
\text { Colle-Buddleja coriacea }\end{array}$ \\
\hline Commercial & 45 & Livestock, agricultural products, market, prepared food \\
\hline Manual labor & 38 & Temporary agricultural labor, carpentry, manufacturing \\
\hline Tourism & 25 & Guiding, animal caretaker, burro rental, cook, boat rental \\
\hline Dairy products & 15 & Milk, cheese \\
\hline Arts/crafts & 15 & Hand spun fabrics, clothing, ceramics \\
\hline
\end{tabular}


of vulnerability as households are already very marginalized which significantly weakens their resilience and ability to adapt to rapid shifts in the natural resources upon which they depend for their livelihoods.

\subsection{Emerging human vulnerabilities}

The hydrology research presented in the previous section demonstrates through an instrument-based analysis that glacial recession in the Cordillera Blanca has increased rapidly in the latter half of the twentieth Century and that it is currently affecting the composition of water resources and seasonal glacial discharge rates. We conducted a complementary social evaluation of the ways in which the people of the Yanamarey watershed perceive these changes through their daily experiences and during the recent past. Household perceptions of glacier recession in the region are very strongly correlated with our instrument-based findings. Case-study respondents indicated unanimously that significant glacier recession has taken place in the region. Interviewees consistently indicated that there is much less snow and ice in the upper watersheds than in the past and that the glaciers are disintegrating continuously, often collapsing in the form of "giant blocks" (YS6 2008, Household interview, Yanamaray. 30 July 2008), and that the changes are, as one respondent indicated, "strong and obvious" (YS17 2008, Household interview, Yanamaray. 5 August 2008).

Household accounts also confirmed that the glaciers have been receding for at least the past several decades. On average, interviewees noted that the glaciers began to recede very quickly around 15 years ago. Most responded that before this period the "mountains were covered in snow" (YS15 2008, Household interview, Yanamaray. 5 August 2008), but since then it has been disappearing "year by year" (YS21 2008, Household interview, Yanamaray. 5 August 2008). Consequently, as one person suggested, the white peaks of the range are becoming "black" with bare rock (YS13 2008, Household interview, Yanamaray. 31 July 2008). Several older respondents, who recall changes from the past 50 years, stated that glacier recession in the region began early in their lives. These accounts by older respondents are particularly salient as they cover a period of time before any instrumentation or satellites were in place and are thus the only observational record we are likely to establish. For example, one 50 year-old male respondent stated "when I was nine years old the quantity of ice was $100 \%$ today the snow has receded considerably, uncovering rocks where ice existed before" (YS39 2008, Household interview, Yanamaray. 5 August 2008). In addition households also indicated that the rate of glacier recession in the watershed has increased substantially in the past few years. One respondent indicated, for example, "when it gets warm it [the snow] now disappears twice as fast" (YS27 2008, Household interview, Yanamaray. 5 August 2008).

That households are able to discuss these changes in great detail and over relatively long temporal scales of time is not surprising given the importance of glaciers in their lives. Household respondents confirmed that glaciers occupy a unique and important nexus of social and cultural meaning in the Andes and therefore their activities are closely monitored by people living beneath their expanses, similar to the findings of other recent research (Bolin 2001; Cruikshank 2005; Orlove et al. 2008). In addition, because glaciers dominate the most precipitous terrain in the region, ablation events are often very loud and the sound of falling ice, rocks or snow reverberates long distances through the high glaciated canyons. While glaciers 
in the Yanamarey watershed are not directly threatening to local human populations, the Cordillera Blanca's history of devastating natural disasters linked to glacial recession has clearly had an important psychological impact on residents throughout the region. Sudden rock and ice avalanches or many other types of hazards pose great risks to a large percentage of the human population of the region and over the course of the past half century these events have had disastrous impacts on human populations. ${ }^{5}$

Overall, household perceptions of glacial shifts in the region strongly confirm that current rates of glacier recession have been increasing. Interviewees also indicated that the rapid disappearance of many glaciers is deeply worrying. As one 55 year old male interviewee stated, the cascading set of problems facing the region are "total deglaciation, irreversible warming, [and] negative changes for humanity" (YS23 2008, Household interview, Yanamaray. 5 August 2008). Overall, 91\% of respondents indicated that they are deeply preoccupied by recent climate change taking place in the region. ${ }^{6}$ Interviewees stated that they were very concerned about the impacts of climate change on family and livestock health (44\%), agricultural productivity (42\%), water availability $(25 \%)$ and fish stocks $(8 \%) .{ }^{7}$ Respondents also indicated that many of these factors are already negatively affecting their lives. For example, more than $94 \%$ of interviewees from households engaged in agriculture, livestock production or tourism activities indicated that they have noted significant changes in their activities due to recent climate change. ${ }^{8}$ These include shifts in water availability and increasingly extreme variability in seasonal weather patterns, temperature and rainfall.

\subsubsection{Shifting water variability}

As described above, primary livelihood production strategies in the Yanamarey valley are highly dependent on water resources, which are provided partly by glacial melt during the dry season. While our instrumental analyses of hydrological shifts in the region are still tentative (See Section 2), our case-study household respondents stated very strongly that they are witnessing substantial shifts in water resources in the watershed. A majority of interviewees indicated that, despite some inter-annual variation, dry season water availability is in an overall state of decline and many

\footnotetext{
${ }^{5}$ Glacier hazards are a critically important factor affecting human vulnerability in the region. This research was not specifically directed towards evaluating the risks that the increasingly unstable and rapidly melting glaciers pose for inhabitants, though they were often discussed with interviewees. Since 1702, more than 22 catastrophic glacial-related disasters have occurred in the region resulting in the deaths of thousands of people and the destruction of entire urban centers including Huaraz. This includes one of the largest glacier-related disasters in recorded history. In 1970, an earthquake precipitated a huge avalanche down the face of Huascaran. The rock and ice buried the town of Yungay and approximately 23,000 people perished (Morales Arnao 1998). See Carey (2007, in press), Hegglin and Huggel (2008), Klimeš et al. (2009), Silverio and Jaquet (2003), and Vilímek et al. (2005) for more extensive discussions of glacier hazards in the region and the political economy of glacial hazards.

${ }^{6}$ The confidence interval for this response is $\pm 4.3 \%$ ( $95 \%$ level).

${ }^{7}$ Respondents often mentioned more than one concern so the cumulative percentage is more than 100 .

${ }^{8}$ The confidence interval for this response is $\pm 3.66 \%$ ( $95 \%$ level).
} 
respondents stated that in recent years during the dry season they have experienced water shortages relative to the quantities available in the past.

Historically the glaciers of the region have generally offered human populations a relatively abundant and regular supply of water. ${ }^{9}$ Case-study households utilize water resources from several different watersheds based on their vertical location. The Yanamarey watershed supports hundreds of water users, though households below Lake Querococha also access water flowing from the Cotush and Queshque watersheds. Nearly all of the case-study interviewees (93\%) noted that over the course of the past decade (ranging from between 3 and 10 years) water supplies have been decreasing in these watersheds during the dry season. ${ }^{10}$ In addition, households also reported significant drops in the dry-season levels of nearby lakes (including Querococha) and reduced water flows from many springs towards the final months of the dry season.

While households overwhelmingly indicated that water supplies are declining throughout the Catac region during the dry season, there still appears to be sufficient quantities of water for human consumptive needs (See Table 1). Nevertheless, in the Yanamarey watershed and in the town of Catac, interviewees did indicate that access to these water resources is becoming increasingly difficult during the dry season and that many of the smaller streams and seasonal springs have become more intermittent than in the past. Additionally, in the town of Catac, recent urban growth has been placing increasing pressure on the water system that is managed by the municipality. Municipal authorities are seeking to expand the water delivery system, which is likely to put even more pressure on water supplies throughout the region during the dry season.

The reported decline of water resources during the dry season has had the most significant impacts on agricultural and livestock activities. As Table 1 illustrates, a majority of households depend on seasonal irrigation to cultivate agricultural products on small parcels of land. A number of interviewees reported that canal water levels have been dropping steadily over the past few years and it has become increasingly difficult to access enough water to maintain crop production levels. In and around the municipality of Catac, access to irrigation water during the dry season has become an acute problem. Because it is widely recognized that water supplies have been decreasing, the municipality recently instituted a water rationing system that has nearly eliminated most agricultural production during the dry season.

Declining water resources during the dry season have also negatively affected livestock production. In the upper Yanamarey watershed, which is controlled by the Campesino Community, only 15 user groups (monadas) are granted grazing access to the zone per year and grazing activities are monitored by community authorities. Despite community management efforts to curtail overgrazing and pasture degradation, households and community watershed managers indicated that the seasonal

\footnotetext{
${ }^{9}$ Water resources have never been shared equally as control of water resources and water governance haw always been a key source of contention and struggle in the region. Furthermore, water resources are not distributed evenly throughout the region. The Cordillera Negra, for example, which forms the western half of the Callejon de Huaylas drainage has very few sources of water.

${ }^{10}$ The confidence interval for this response is $\pm 3.61(95 \%)$ level. In addition to noting significant decreases in the flow of water, $85 \%$ of households indicated that overall there was less water, while $13 \%$ noted there had been no significant changes and only $2 \%$ noted that there are actually more water resources. The confidence interval for this response is $\pm 5.06(95 \%)$.
} 
decline of stream and spring flows have negatively affected pasture health and grass productivity. In addition, because some smaller streams have recently begun to disappear during certain periods of the year, access to sufficient water for livestock now requires more frequent and greater daily vertical movement of animals, which has increased the intensity of herding and negatively affected livestock growth rates. Finally, respondents along the length of the watershed indicated that fish stocks have either declined precipitously or have completely disappeared in many streams. This is possibly due, in part, to seasonal reductions of fish habitat in the upper watershed.

Overall, new stress on water resources from irrigation, livestock production and human consumption are escalating not only within the Catac region, but also along the entire drainage system below the town of Catac. In 2008, the Peruvian National Soil and Water Conservation Agency (PRONOMACH) began to construct new downstream water diversions from Lake Querococha in response to new water rights claims by several downstream communities. Several case study respondents indicated that conflicts within the community and around the region over access to irrigation water have been increasing and that they expect them to become more prevalent as water resources continue to decline. These conflicts are likely to be exacerbated even further by growing urban water demand in Huaraz and other urban centers.

\subsubsection{Increasing weather extremes}

Recent research demonstrates that climate change is shifting average temperatures upwards throughout the tropical Andes and that these alterations will be enhanced at the highest elevations by the end of this century (Bradley et al. 2004, 2009; Urrutia and Vuille 2009; Vuille and Bradley 2000). A number of climatic shifts are also taking place across the Amazon Basin, which is the primary source of most of the rainfall in the Cordillera Blanca during non-El Niño years (Avissar and Werth 2005; Betts et al. 2008; Cox et al. 2008). While this research informs our understanding of these processes at a broad scale of analysis for the region, it is not always useful for evaluating shifts at more local and human scales of analysis. In the Cordillera Blanca, even regional-based research efforts are complicated by the fact that meteorological data for the region are temporally and spatially sporadic and that climatic conditions are highly diverse across the rugged topography of the entire mountain range. ${ }^{11}$

Even less research has engaged with local populations to evaluate their understanding of the ways in which meteorological transformations might be affecting livelihoods and human capabilities (though see Rhoades et al. 2006). Because shifts in precipitation and temperature are often very short-term in nature and specific to certain places, human perceptions of these changes are frequently very difficult to deduce from regional models, in situ instrumentation or remotely sensed data. In the Andes, human perception of meteorological events are also dependent on a host of factors such as coincidental co-location, temporal factors such as time of day and season, clothing, shelter, human sensory perception and cultural factors (Orlove et al. 2008; Strauss and Orlove 2003). Despite these limiting factors, 95\% of our case-study respondents responded that significant and often extreme shifts in temperature variation, precipitation patterns and seasonal change have been occurring with greater

\footnotetext{
${ }^{11}$ Recent research addressing meteorological shifts in the Andes include (Aguilar et al. 2005; Diaz et al. 2003; Quintana-Gomez 1999; Vincent et al. 2005).
} 
frequency and intensity across the region. ${ }^{12}$ Many of these factors are interacting in complex and nonlinear ways with the more gradual hydrological and ecological changes discussed in previous sections such that they often intensify vulnerability and risk factors for livelihoods and are often the most critical issues for extremely marginal natural resource based livelihoods.

In the Yanamarey area, the largest impacts of increasing climatic extremes are falling upon the most susceptible households that lack adequate shelter and clothing. In the town of Catac, housing structures are often built with cement floors, tin or tile roofs, single pane windows and cement or adobe walls. In rural areas, structures more frequently have earthen floors, adobe or natural rock walls and either tin or grass roofing. Internal heating is virtually nonexistent throughout the region and households often cook with firewood or manure. Clothing often consists of handspun woolen ponchos and footwear may be little more than sandals fashioned from recycled tires (llanquis). Interviewees in both areas repeatedly noted that cold spells and freezes have increased in frequency at night which is leading to an increase in respiratory illnesses, particularly during the rainy season. As several interviewees noted, freezes are now accompanied by "cold until the bones hurt" (YS27 2008, Household interview, Yanamaray. 5 August 2008) and intense storms now descend upon the community that bring with them "gusts that are not in their season, that are strong blows to the health, and that come with sickness" (YS29 2008, Household interview, Yanamaray. 31 July 2008). Many households also noted that colder temperatures in the pre-dawn hours increasingly limit their ability to herd livestock long distances as the extreme cold prevents them from leaving their shelters until after sunrise.

Weather extremes are also significantly affecting agricultural production in the community. Respondents indicated that periods of intense heat and sunlight are drying out the grasslands and crops. These events are often punctuated by intense convective precipitation events, powerful winds and hail that damage crops. Interviewees also indicated that the frequency and intensity of low temperature frosts have increased during both the rainy and dry seasons, which regularly damages crops as well. Of the households that reported some form of agricultural activity, 91\% reported that recent freezes have affected their crops, which include wheat, corn and potatoes. Households also indicated that rainfall patterns have shifted significantly and that it is raining more frequently during the dry season and less consistently during the traditional rainy season. Interviewees stated that these precipitation shifts have confused the traditional agricultural calendar and that they are increasingly uncertain when to plant or harvest their crops. These shifting seasonal patterns have also come with great risk to household food security as interviewees reported a higher frequency of failed or damaged crops in recent years relative to the past.

Livestock production has also been affected both directly and indirectly by increasing weather extremes, which was widely noted by households. Respondents indicated that increases in frost events have weakened livestock and increased the frequency and severity of animal disease. Households also noted that the grasses in grazing areas are increasingly stunted in growth or prematurely dry, changes which were attributed to less regularity in rainfall patterns, more frequent and severe

${ }^{12}$ The confidence interval for this response is \pm 3.61 ( $95 \%$ level). 
frosts, more intense solar radiation, as well as increasing grazing pressure in some areas. Respondents reported that a lack of high quality fodder was contributing to low weight gain in their livestock and to increasing susceptibility to disease. Finally, households also noted that new animal diseases have appeared in the region. While this research was not able to confidently evaluate the relationship between animal diseases and shifting climatic variables, a wide variety of animal diseases were inventoried which include anthrax, liver flukes and other parasites, respiratory diseases, insect infestations, and a variety of infections.

\subsubsection{Threats to tourism}

Glacier recession also poses serious threats to tourism activities in the region as the Cordillera Blanca is a well known global tourist destination for climbers, backpackers and other outdoor adventurers. Several locations are also visited frequently by Peruvian tourists from Lima as part of school trips and during holiday periods. Tourist destinations in Catac are concentrated in a few locations that include Lake Querococha, which is on the route to the pre-Incan archaeological site of Chavin, and the Pastoruri glacier. Pastoruri is one of the most accessible glaciers in the entire range and hosts a number of rare endemic plant species such as the Puya raimondii. Tourism visits to the region have increased significantly over the past decade. Between 1997 and 2006, tourist visits to the highlands of the Department of Ancash increased 57\%. In 2006, Pastoruri was the second most visited location in Huascaran National Park and, according to park records, 42,404 people visited the area (INEI 2006). These flows of tourists are critical sources of income for residents in the Catac region. As Table 2 indicates, $25 \%$ of surveyed households are engaged in some form of tourism-based activity, which includes the production of arts and crafts, animal rentals, guide services and food and refreshment preparation at both tourist sites and along the main thoroughfare of town, where busloads of tourists often stop to dine.

Over the course of the past few years, households have been affected by a number of climate-change induced shocks to tourism. In late 2007, the Pastoruri glacier became the first tourism destination in Peru to be closed due to "adverse climatic conditions" The glaciological office in Huaraz announced that the glacier was rapidly disappearing due both to the impacts of too many people degrading its surface and climate change (INRENA 2008). The closure of the glacier had profound negative consequences for the residents of Catac which resulted in a number of heated conflicts, protests and road blockades by the Campesino Community. After tense and protracted negotiations, the creation of new visitor guidelines, the prohibition of any further glacier crossings and the rerouting of a trail to the base of the glacier, the area was re-opened to tourists. However, the glaciological office estimates that these measures are only temporary as the glacier will still disappear by 2015 as a result of rapidly increasing temperatures (Flores 2008). Tourism throughout the range is similarly threatened by glacier recession, particularly because many of the popular climbing routes are becoming more dangerous as icefalls and avalanches are increasing in frequency. Overall, aside from the occasional sales of animals, tourism is one of the most important sources of cash income for many of the case-study households. As such it represents a particularly important livelihood activity as households have few opportunities to generate critically important financial resources to purchase durable goods, housing materials, clothing and other vital materials. Consequently, 
the threats that glacier recession pose to tourism, and the manner in which they might be managed, have intensified conflicts between conservationists, park managers and community members seeking different solutions and are likely to be a source of continuous contention in the future.

\section{Conclusions}

As the previous sections suggest, recent glacier recession and shifts in climate in the Cordillera Blanca have been increasing the vulnerability of household livelihoods in the Yanamarey watershed through threats to tourism related activities, the occurrence of extreme weather events and increasingly variable access to water resources. While these particular vectors are most salient for households and communities in the watershed, further comparative research will enable a more comprehensive evaluation of how households situated across different elevation gradients and production networks along the entire mountain range are being affected. However, these are not the only factors driving social and environmental change. Consequently, they must also be understood to be historically contingent on and mutually constitutive with broader social and environmental processes. This includes the historical legacy of exploitation and inequality that has fostered the very high extreme poverty rates for the region, new economic growth in the mining and tourism sector and the presence of a host of other actors throughout the country and downstream that are also being affected by these changes, which include very powerful urban, hydroelectric and export-led agricultural interests. In addition, as debates over the current and future distribution and management of these water resources begin to intensify, the potential for conflicts between these actors will also increase significantly. Finally, while this research focuses on new forms of household livelihood vulnerability in the Cordillera Blanca, we have not yet evaluated the potential capabilities of households to adapt to these changes or how household activities might already be changing. This is particularly important for future development efforts that might support adaptation and capacity building activities in the region and something that we will address in future work. ${ }^{13}$

Our case study also provides an important example of the scale-dependent complexity of climate-environmental impacts on tropical glacier-hydrology that is both a problem and opportunity for integrated research. Detailed glacier-specific Andean research has shown that while temperature may correlate regionally with overall glacier recession, the tropical glacier surface energy budget is not predominantly responsive to sensible heat (Vuille et al. 2008b). Other variables like humidity and precipitation play critical roles in moderating the local radiation balance that dominates mass balance. Likewise, while the mass changes to the Yanamarey glacier have shown sensitivity to climate consistent with "enhanced greenhouse" forcing

\footnotetext{
${ }^{13}$ During the summer of 2009 the authors participated in a multi-disciplinary conference with researchers, policy makers and civil society organizations focused on human adaptation to glacier recession in the region. This event, "Adapting to a World without Glaciers" received support from a variety of organizations including the The Mountain Institute, the National Science Foundation, USAID and several Peruvian institutions (Recharte et al. 2009). A number of research goals and a larger USAID funded project have emerged from these activities.
} 
related to anthropogenic warming, our dataset does not have long enough continuous records to permit meaningful trend analyses or explore other relationships with precipitation. For example, an earlier analysis has shown a positive correlation between annual temperature and precipitation anomalies at YAN (Mark 2006). Mean monthly temperature traces a statistically significant decreasing trend over the past 5 years while glacier recession has reached maximum rates, yet this record is too short to include ENSO events that have been demonstrated to impact glacier mass balance and precipitation inconsistently in this region (Francou et al. 1995; Vuille et al. 2008a). In addition, currently measurements do not have adequate resolution to document the relative magnitude of the specific extreme weather events that are reported to impact livelihoods, which is also one of the major limitations of most climate change modeling efforts and why coupled analyses of human-environment dynamics that include spatially distributed social analyses as well as hydroclimatic measurements and monitoring are critically important for future policy and scientific research. We recently designed new methodological tools to begin to address these monitoring and measurement concerns as they constitute a key bridging factor for human-relevant climate modeling change research in the future.

Acknowledgements This research was supported by a National Geographic Explorer Grant and a Collaborative NSF Geography and Spatial Sciences Grant (BCS 0752175). Additional support for the research was provided by NASA and The University of California, Santa Cruz, Faculty Senate. The authors would like to thank the anonymous reviewers for their efforts, the staff of Peru's Glaciological Office in Huaraz, the community of Catac, and our Peruvian field research team.

Open Access This article is distributed under the terms of the Creative Commons Attribution Noncommercial License which permits any noncommercial use, distribution, and reproduction in any medium, provided the original author(s) and source are credited.

\section{References}

Adger W (2006) Vulnerability. Glob Environ Change 16:268-281

Aguilar E, Peterson TC, Ramírez Obando P, Frutos R, Retana JA, Solera M, Soley J, Gonzalez Garcia I, Araujo RM, Rosa Santos A (2005) Changes in precipitation and temperature extremes in Central America and northern South America, 1961-2003. J Geophys Res 110:D23107

Alcamo J, Dronin N, Endejan M, Golubev G, Kirilenko A (2007) A new assessment of climate change impacts on food production shortfalls and water availability in Russia. Glob Environ Change 17:429-444

Ames A (1998) A documentation of glacier tongue variations and lake developments in the Cordillera Blanca. Z Gletsch kd Glazialgeol 34:1-26

Ames A, Dolores S, Valverde A, Evangelista P, Javier D, Gavnini W, Zuniga J, Gómez V (1989) Glacier inventory of Peru, part 1 . Hidrandina, SA, Huaraz, p 105

Avissar R, Werth D (2005) Global hydroclimatological teleconnections resulting from tropical deforestation. J Hydrometeorol 6:134-145

Baraer M, McKenzie JM, Mark B, Bury J (2008) Climate change related evolution of water resources in the Cordillera Blanca, Peru. The Andes: challenge for the geosciences. In: EGU topical conference series, 4th Alexander von Humboldt international conference, Santiago, Chile

Baraer M, McKenzie JM, Mark BG, Bury J, Knox S (2009) Characterizing contributions of glacier melt and ground water during the dry season in the Cordillera Blanca, Peru. Adv Geosci 22:41-49

Barnett TP, Adam JC, Lettenmaier DP (2005) Potential impacts of a warming climate on water availability in snow-dominated regions. Nature 438:303-309

Barry RG, Seimon A (2000) Research for mountain area development: climatic fluctuations in the mountains of the Americas and their significance. Ambio 29:364-370

BCRP (2009) Economic synthesis for Ancash, January 2009. Central Bank of Peru, Lima 
Bebbington AJ, Bury JT (2009) Institutional challenges for mining and sustainability in Peru. Proc Natl Acad Sci U S A 106(41):17296-17301

Betts RA, Malhi Y, Roberts JT (2008) Review. The future of the Amazon: new perspectives from climate, ecosystem and social sciences. Philos Trans R Soc Biol Sci 363:1729-1735

Blaikie P (1994) At risk: natural hazards, people's vulnerability, and disasters. Routledge, London

Bohle H, Downing T, Watts M (1994) Climate change and social vulnerability. Toward a sociology and geography of food insecurity. Glob Environ Change 4:37-48

Bolin I (2001) When Apus are losing their white ponchos environmental dilemmas and restoration efforts in Peru. Dev Coop 6:25-26

Bradley RS, Keimig FT, Diaz HF (2004) Projected temperature changes along the American cordillera and the planned GCOS network. Geophys Res Lett 31:L16210

Bradley RS, Vuille M, Diaz HF, Vergara W (2006) Climate change: threats to water supplies in the tropical Andes. Science 312:1755-1756

Bradley RS, Keimig FT, Diaz HF, Hardy DR (2009) Recent changes in freezing level heights in the Tropics with implications for the deglacierization of high mountain regions. Geophys Res Lett 36:L17701

Brecher HH, Thompson LG (1993) Measurement of the retreat of Qori Kalis glacier in the tropical Andes of Peru by terrestrial photogrammetry. Photogramm Eng Remote Sensing 59:1017-1022

Brooks N, Adger WN (2003) Country level risk measures of climate-related natural disasters and implications for adaptation to climate change. Working paper 26, Tyndall Center for Climate Change Research

Burton I, White G, Kates R (1978) The environment as hazard. Oxford University Press, New York

Bury J (2005) Mining mountains: neoliberalism, land tenure, livelihoods, and the new Peruvian mining industry in Cajamarca. Environ Plann A 37:221-239

Carey M (2005) Living and dying with glaciers: people's historical vulnerability to avalanches and outburst floods in Peru. Glob Planet Change 47:122-134

Carey M (2007) The history of ice: how glaciers became an endangered species. Environ Hist 12:497

Carey M (2010) In the shadow of melting glaciers: climate change and Andean Society. Oxford University Press, New York

Casassa G, Espizua LE, Francou B, Ribstein P, Ames A, Alean J (1998) Glaciers in South America. Stud Rep Hydrol 56:125-146

CCC (2006) Biodiversity conservation plan for the Campesino community of Catac-Huascaran National Park. Campesino Community of Catac, Catac

CEPES (1996) Agrarian law and Campesino communities. Center for Peruvian Social Studies, Lima

Clark W, Parson E, Research, Project ASfS, Science BCf, Affairs I, Environment, Program NR (2000) Assessing vulnerability to global environmental risks. Belfer Center for Science and International Affairs, John F Kennedy School of Government, Harvard University, Cambridge

CONAM (2001) National communication of Peru to the United Nations climate change convention. National Council on the Environment, Lima

Cox PM, Harris PP, Huntingford C, Betts RA, Collins M, Jones CD, Jupp TE, Marengo JA, Nobre CA (2008) Increasing risk of Amazonian drought due to decreasing aerosol pollution. Nature 453:212-215

Cruikshank J (2005) Do glaciers listen?: local knowledge, colonial encounters, and social imagination. Univ of British Columbia Press, Vancouver

Cutter S (1996) Vulnerability to environmental hazards. Prog Hum Geogr 20:529-539

Cutter S (2003) The vulnerability of science and the science of vulnerability. Ann Assoc Am Geogr 93:1-12

Del Castillo L (2005) Campesino communities in the 21st century: status and normative changes. Center for Peruvian Social Studies, Lima

Diaz HF, Eischeid JK, Duncan C, Bradley RS (2003) Variability of freezing levels, melting season indicators, and snow cover for selected high-elevation and continental regions in the last 50 years. Clim Change 59:33-52

Dillehay T, Kolata A (2004) Long-term human response to uncertain environmental conditions in the Andes. Proc Natl Acad Sci 101:4325-4330

Dyurgerov M (2003) Mountain and subpolar glaciers show an increase in sensitivity to climate warming and intensification of the water cycle. J Hydrol 282:164-176

Eakin HC (2006) Weathering risk in rural Mexico: climatic, institutional, and economic change. Univ of Arizona Press, Tucson

Eakin H, Luers AL (2006) Assessing the vulnerability of social-environmental systems. Annu Rev Environ Resour 31:365-394 
Eakin HC, Wehbe MB (2009) Linking local vulnerability to system sustainability in a resilience framework: two cases from Latin America. Clim Change 93:355-377

Fagre DB, Peterson DL, Hessl AE (2003) Taking the pulse of mountains: ecosystem responses to climatic variability. Clim Change 59:263-282

Flores AC (2008) Impacts, vulnerability, mitigation and adaptation to the effects of climate change on water resources. National Institute of Natural Resources, Huaraz

Francou B, Coudrain A (2005) Glacier shrinkage and water resources in the Andes. EOS Trans Am Geophys Union 86:415

Francou B, Ribstein P, Semiond H, Portocarrero C, Rodriguez A (1995) Balances de glaciares y clima en Bolivia y Peru: impacto de los eventos ENSO. Bull Inst Fr Etudes Andines 24:661670

Füssel H (2007) Vulnerability: a generally applicable conceptual framework for climate change research. Glob Environ Change 17:155-167

Georges C (2004) The 20th century glacier fluctuations in the tropcial Cordillera Blanca, Peru. Arct Antarct Alp Res 36:100-107

Hastenrath S, Ames A (1995a) Diagnosing the imbalance of Yanamarey Glacier in the Cordillera Blanca of Peru. J Geophys Res 100:5105-5112

Hastenrath S, Ames A (1995b) Recession of Yanamarey glacier in Cordillera Blanca, Peru, during the 20th century. J Glaciol 41:191-196

Hegglin E, Huggel C (2008) An integrated assessment of vulnerability to glacial hazards. Mt Res Dev 28:299-309

Hewitt K (1983) Interpretations of calamity. Allen \& Unwin, Boston

IARU (2009) Rising sea levels set to have major impacts around the world. In: Conference on climate change: global risks, challenges and decisions, 10-12 March, International Alliance of Research Universities, University of Copenhagen, Copenhagen

INEI (2006) Ancash statistical compendium. National Institute of Statistics and Information, Lima

INEI (2007) The 2007 national census: XI of population and VI of houses. Institute of National Statistics and Information, Lima

INRENA (2008) INRENA closes pastoruri peak due to adverse climatic conditions. Peruvian Institute of Natural Resources, Lima

IPCC (2007a) Climate change 2007: the physical science basis. Intergovernmental Panel on Climate Change, Geneva

IPCC (2007b) Impacts, adaptation and vulnerability. Working group II contribution to the fourth assessment report of the IPCC. Cambridge University Press, Cambridge

Juen I, Kaser G, Georges C (2007) Modelling observed and future runoff from a glacierized tropical catchment (Cordillera Blanca, Peru). Glob Planet Change 59:37-48

Kaser G (1999) A review of the modem fluctuations of tropical glaciers. Glob Planet Change 22:93103

Kaser G, Osmaston H (2002) Tropical glaciers. Cambridge University Press, Cambridge

Kaser G, Ames A, Zamora M (1990) Glacier fluctuations and climate in the Cordillera Blanca, Peru. Ann Glaciol 14:136-140

Kaser G, Juen I, Georges C, Gómez J, Tamayo W (2003) The impact of glaciers on the runoff and the reconstruction of mass balance history from hydrological data in the tropical Cordillera Blanca, Peru. J Hydrol 282:130-144

King G, Keohane R, Verba S (1994) Designing social inquiry. Princeton University Press, Princeton

Kinzl H (1942) Gletscherkundliche Begleitworte zur Karte der Cordillera Blanca (Peru). Z Glestch 28:1-19

Kinzl H, Ebster F, Gotthardt E, Heckler K, Schneider E (1964) Begleitworte zur Karte 1:100.000 der Cordillera Blanca (Peru) Sudteil. Wissenschaft Alpenvereinshefte, 17 edn. Universitätsverlag Wagner, Innsbruck

Klimeš J, Vilímek V, Omelka M (2009) Implications of geomorphological research for recent and prehistoric avalanches and related hazards at Huascaran, Peru. Nat Hazards 50:193-209

Kundzewicz Z, Mata L, Arnell N, Döll P, Jimenez B, Miller K, Oki T, Sen Z, Shiklomanov I (2008) The implications of projected climate change for freshwater resources and their management. Hydrol Sci J 53:3-10

Leichenko RM, O'Brien K (2008) Environmental change and globalization: double exposures. Oxford University Press, USA

Liverman D (1990) Drought impacts in Mexico: climate, agriculture, technology, and land tenure in Sonora and Puebla. Ann Assoc Am Geogr 80:49-72 
Magrin G, Gay C, Cruz D, Giménez J, Moreno A, Nagy G, Nobre C, Villamizar A (2007) Latin America, climate change 2007: impacts, adaptation and vulnerability. Contribution of working group II to the Fourth Assessment Report of the IPCC, pp 581-615

Mark BG (2002) Hot ice: glaciers in the tropics are making the press. Hydrol Process 16:3297-3302

Mark BG (2006) Quantifying the significance of recent glacier recession in the Cordillera Blanca, Perú: a case study of hydrological impact and climatic control. In: Knight P (ed) Glacier science and environmental change. Blackwell, Oxford, pp 242-245

Mark BG, Seltzer GO (2003) Tropical glacier meltwater contribution to stream discharge: a case study in the Cordillera Blanca, Peru. J Glaciol 49:271-281

Mark BG, Seltzer GO (2005) Evaluation of recent glacier recession in the Cordillera Blanca, Peru (AD 1962-1999): spatial distribution of mass loss and climatic forcing. Quat Sci Rev 24:2265-2280

Mark BG, McKenzie JM, Gómez J (2005) Hydrochemical evaluation of changing glacier meltwater contribution to stream discharge: Callejon de Huaylas, Peru. Hydrol Sci J 50:975-987

Mark BG, Bury J, French A, McKenzie J, Baraer M, Huh K (2010) Climate change and tropical Andean glacier recession: evaluating hydrologic changes and livelihood vulnerability in the Cordillera Blanca, Peru. Ann Assoc Am Geogr (in press)

MEM (2008) Electrical statistics 2008. Ministry of Energy and Mines, Lima

Messerli B (2001) The International Year of the Mountains (IYM), the Mountain Research Initiative (MRI) and PAGES, editorial. PAGES News 9:2

Milner AM, Brown LE, Hannah DM (2009) Hydroecological response of river systems to shrinking glaciers. Hydrol Process 23:62-77

Morales Arnao B (1998) Glaciers of South America-glaciers of Peru. In: Williams RS, Ferrigno JG (eds) Satellite image atlas of glaciers of the world, 1386 edn. United States Government Printing Office, Washington

Morales Arnao B, Hastenrath S (1998) Glaciers of South America-glaciers of Peru. In: Williams RS, Ferrigno JG (eds) Satellite image atlas of glaciers of the world, 1386 edn. United States Government Printing Office, Washington

Morton JF (2007) The impact of climate change on smallholder and subsistence agriculture. Proc Natl Acad Sci U S A 104:19680-19685

Nogues-Bravo D, Araujo MB, Errea MP, Martinez-Rica JP (2007) Exposure of global mountain systems to climate warming during the 21st century. Glob Environ Change 17:420-428

Orlove B (2009) Glacier retreat: reviewing the limits of human adaptation to climate change. Environment 51:22-34

Orlove B, Wiegandt E, Luckman BH (2008) Darkening peaks: glacier retreat, science, and society. Univ of California Press, Berkeley

Painter J (2007) Deglaciation in the Andean Region. United Nations Development Programme, New York

Pearsall DM (2008) Plant domestication and the shift to agriculture in the Andes. In: Silverman H, Isbell WH (eds) The handbook of South American Archaeology. Springer, New York, pp 105120

Peet R, Watts M (2004) Liberation ecologies: environment, development, social movements. Routledge, London

PETT (2002) Special land titling and rural cadastral project (PETT). Ministry of Agriculture, Lima

Polsky C, Neff R, Yarnal B (2007) Building comparable global change vulnerability assessments: the vulnerability scoping diagram. Glob Environ Change 17:472-485

Pozorski S, Pozorski T (2008) Early cultural complexity on the coast of Peru. In: Silverman H, Isbell WH (eds) The handbook of South American Archaeology. Springer, New York, pp 607-631

Pulgar Vidal J (1981) Geografía del Perú. Las ocho regiones naturales del Perú. 8va. edición. Editorial Universo, Lima

Quintana-Gomez RA (1999) Trends of maximum and minimum temperatures in northern South America. J Climate 12:2104-2112

Racoviteanu A, Arnaud Y, Williams M (2008) Decadal changes in glacier parameters in Cordillera Blanca, Peru derived from remote sensing. J Glaciol 54:499-510

Recharte J, Zapata F, Postigo J, Avellaneda L, Tarazona J (2009) Adapting to a world without glaciers. The Mountain Institute, Lima

Rhoades RE, Rfos XZ, Aragundy J (2006) Climate change in Cotacachi. In: Rhoades R (ed) Development with identity: community, culture and sustainability in the Andes. CABI, Cambridge, pp 64-74 
Rosenzweig C, Strzepek KM, Major DC, Iglesias A, Yates DN, McCluskey A, Hillel D (2004) Water resources for agriculture in a changing climate: international case studies. Glob Environ Change Part A 14:345-360

Silverio W, Jaquet JM (2003) Mapping by remote sensing of glacier-induced natural hazards, Cordillera Blanca, Peru. Arch Sci 56:39-58

Stewart I (2009) Changes in snowpack and snowmelt runoff for key mountain regions. Hydrol Process 23:78-94

Strauss S, Orlove BS (2003) Weather, climate, culture. Berg, New York

Thomalla F, Downing T, Spanger-Siegfried E, Han G, Rockstrom J (2006) Reducing hazard vulnerability: towards a common approach between disaster risk reduction and climate adaptation. Disasters 30:39-48

Thompson LG (2000) Ice core evidence for climate change in the Tropics: implications for our future. Quat Sci Rev 19:19-35

Thompson LG, Brecher HH, Mosley-Thompson E, Hardy DR, Mark BG (2009) Glacier loss on Kilimanjaro continues unabated. Proc Natl Acad Sci U S A 106:19770-19775

Thompson LG, Mosley-Thompson E, Brecher H, Davis M, León B, Les D, Lin PN, Mashiotta T, Mountain K (2006) Abrupt tropical climate change: past and present. Proc Natl Acad Sci U S A 103:10536

Turner B, Robbins P (2008) Land-change science and political ecology: similarities, differences, and implications for sustainability science. Annu Rev Environ Resour 33:295-316

Turner B, Kasperson R, Matson P, McCarthy J, Corell R, Christensen L, Eckley N, Kasperson J, Luers A, Martello M (2003) A framework for vulnerability analysis in sustainability science. Proc Natl Acad Sci U S A 100:8074-8079

UNDP (2007) Fighting climate change: human solidarity in a divided world. United Nations Development Program, New York

Urrutia R, Vuille M (2009) Climate change projections for the tropical Andes using a regional climate model: temperature and precipitation simulations for the end of the 21st century. J Geophys Res 114:D02108

USAID (2007) Adapting to climate variability and change. USAID, Washington, DC

Vergara W (2009) Assessing the potential consequences of climate destablization in Peru. The World Bank, Latin American and the Caribbean Region, LCSSD, Washington, DC

Vilímek V, Zapata M, Klimeš J, Patzelt Z, Santillán N (2005) Influence of glacial retreat on natural hazards of the Palcacocha Lake area, Peru. Landslides 2:107-115

Vincent LA, Peterson TC, Barros VR, Marino MB, Rusticucci M, Carrasco G, Ramirez E, Alves LM, Ambrizzi T, Berlato MA (2005) Observed trends in indices of daily temperature extremes in South America 1960-2000. J Climate 18:5011-5023

Viviroli D, Durr HH, Messerli B, Meybeck M, Weingartner R (2007) Mountains of the world, water towers for humanity: typology, mapping, and global significance. Water Resour Res 43:13

Vuille M, Bradley RS (2000) Mean annual temperature trends and their vertical structure in the tropical Andes. Geophys Res Lett 27:3885-3888

Vuille M, Kaser G, Juen I (2008a) Glacier mass balance variability in the Cordillera Blanca, Peru and its relationship with climate and the large-scale circulation. Glob Planet Change 62:14-28

Vuille M, Francou B, Wagnon P, Juen I, Kaser G, Mark BG, Bradley RS (2008b) Climate change and tropical Andean glaciers: past, present and future. Earth-Sci Rev 89:79-96

White G (1973) Natural hazards research. In: Chorley RJ (ed) Directions in geography. Methuen, London

Wisner B, Blaikie PM, Cannon T (2004) At risk: natural hazards, people's vulnerability and disasters. Routledge, London

WMO (2009) The state of polar research: a statement from the international council for science/WMO for the International Polar Year 2007/2008. WMO, Geneva

WorldBank (2008) Development and climate change: a strategic framework for the World Bank Group. World Bank, Washington, DC

Xu J, Grumbine R, Shrestha A, Eriksson M, Yang X, Wang Y, Wilkes A (2009) The melting Himalayas: cascading effects of climate change on water, biodiversity, and livelihoods. Conserv Biol 23:520-530

Young KR (2009) Andean land use and biodiversity: humanized landscapes in a time of change. Ann Mo Bot Gard 96:492-507

Young K, Lipton J (2006) Adaptive governance and climate change in the tropical highlands of western South America. Clim Change 78:63-102 